NBER WORKING PAPER SERIES

\title{
EQUITY MARKET LIBERALIZATIONS AS COUNTRY IPOs
}

\author{
Rodolfo Martell \\ René M. Stulz \\ Working Paper 9481 \\ http://www.nber.org/papers/w9481 \\ NATIONAL BUREAU OF ECONOMIC RESEARCH \\ 1050 Massachusetts Avenue \\ Cambridge, MA 02138 \\ February 2003
}

Respectively, $\mathrm{Ph}$. D. candidate, The Ohio State University, and Reese Chair of Banking and Monetary Economics, The Ohio State University, and NBER. We are grateful to Dong Lee, Andrew Karolyi, Enrico Perotti, Robert Shiller, and Andrei Shleifer for useful comments. This paper was prepared for the session of the January 2003 American Economic Association meetings titled "Debt, equity, and financial openness." The views expressed herein are those of the authors and not necessarily those of the National Bureau of Economic Research.

C)2003 by Rodolfo Martell and René M. Stulz. All rights reserved. Short sections of text not to exceed two paragraphs, may be quoted without explicit permission provided that full credit including notice, is given to the source. 
Equity Market Liberalizations as Country IPOs

Rodolfo Martell and René M. Stulz

NBER Working Paper No. 9481

February 2003

JEL No. F3, G14, G15, F21

\section{ABSTRACT}

Equity market liberalizations are like IPOs, but they are IPOs of a country's stock market rather than of individual firms. Both are endogenous events whose benefits are limited by poor investor protection, agency costs, and information asymmetries. As for stock prices following an IPO, there are legitimate concerns about the efficiency in the period following the liberalization of the stock market returns of countries that liberalize their equity markets. Equity markets of liberalizing countries experience extremely strong performance immediately after the liberalization, but then go through a period of poor performance. This pattern of stock returns is more dramatic for countries with poorer financial development before the liberalization.

\author{
Rodolfo Martell \\ Fisher College of Business \\ The Ohio State University \\ 810 Fisher Hall \\ 2100 Neil Avenue \\ Columbus, OH 43210-1144 \\ martell_11@cob.osu.edu
}

\author{
René M. Stulz \\ Fisher College of Business \\ The Ohio State University \\ 806A Fisher Hall \\ 2100 Neil Avenue \\ Columbus, OH 43210-1144 \\ and NBER \\ stulz_1@cob.osu.edu
}


Equity market liberalizations make shares of common stock of local firms available to a new class of investors, foreign investors. Initial public offerings (IPOs) make shares in existing firms available to a new class of investors, the general public. Equity market liberalizations and IPOs are therefore similar events in that they increase the pool of investors who can invest in firms. We show in this paper that viewing equity market liberalizations as country IPOs helps understand equity market liberalizations better and raises important issues that future research should examine.

Much of the focus of the literature on equity market liberalizations has been to show that they increase stock prices and reduce the cost of capital. ${ }^{1}$ The literature on IPOs has also shown that there is a substantial stock price increase when firms go public. However, this literature has further been concerned with whether the market for IPO stocks is efficient. There is a large controversial literature examining why firms underperform broad stock market indices following IPOs. ${ }^{2}$ We show that countries that liberalize their equity markets have dramatic positive returns in the year following the liberalization, but these dramatic returns are followed by poor returns. This pattern of returns raises the question of whether stock prices overreact to equity market liberalizations. Further, the IPO literature has also tried to answer why some firms go public while others do not. It has shown that firms go public because their owners benefit from them doing so, but market conditions affect which firms go public and at times market conditions are not receptive to IPOs. The literature on equity market liberalizations has mostly ignored the issue of why some countries liberalize their equity

\footnotetext{
${ }^{1}$ See Stulz (2003) for a review of the evidence and the issues.

${ }^{2}$ Ritter and Welch (2002) review the IPO literature.
} 
markets and others do not. We argue that equity market liberalizations do not necessarily benefit the controlling shareholders of large firms in emerging markets, so that we would expect some countries to abstain from liberalizing their equity market if controlling shareholders of large firms have an important impact on the decision to liberalize. Further, the benefits from equity market liberalizations are limited because investors are poorly protected in emerging markets. This poor investor protection limits the extent to which local firms can issue new equity to take advantage of the increase in the pool of investors for their stock.

The analogy between equity market liberalizations and IPOs has obvious limitations. An IPO involves the issuance of shares that had no public market. As a result, the IPO literature has studied extensively how the issue takes place and how it is priced. Much of the IPO literature in the U.S. attempts to understand why the owners of firms that go public leave money on the table at the time of the IPO through the underpricing of the shares sold at that time. Equity market liberalizations have taken place without new shares being sold by firms, and if new shares are sold, they might be secondary offerings by firms whose shares are already traded. Liberalizations taking place through the creation of a country fund involve an IPO, but this IPO typically does not involve the issue of new shares by the firms of the liberalizing country. However, as for IPOs, emerging market liberalizations enable firms to undertake offerings that otherwise they would not have been able to undertake. Further, emerging market liberalizations make it possible for private or public firms in the process of being privatized to go public when they might not have been able to do so otherwise. When secondary offerings take place as part of the emerging market liberalization or subsequently as a result of it, these offerings 
cannot be underpriced in the same way as IPO offerings because a market for the shares already exists. As a result, the literature that deals with the pricing of the shares when they are sold at the IPO has little relevance for emerging market liberalizations.

The literature on equity market liberalizations has emphasized the risk-sharing benefit of equity market liberalizations. As foreign investors invest in the stocks of liberalizing countries, the risk of these stocks is shared among more investors. As local investors bear less of the risk of local stocks, the risk premium on these stocks falls, their price increases, and the country's cost of capital is reduced. The literature has also been concerned about whether equity market liberalizations increase stock return volatility, but they do not seem to do so in a way that would justify concern. Given the clear benefits and less decisive costs of equity market liberalizations, countries should be eager to liberalize their equity markets, but few have done so fully. Further, Bekaert and Harvey (2000) show that the cost of equity capital falls by roughly 100 basis points following equity market liberalizations. In economic terms, the effect is therefore rather limited. The risk-sharing benefit theory cannot explain why the number of countries that liberalize their equity markets over the last twenty years is relatively small, why the impact of equity liberalizations on the cost of capital has been so limited, and why long-run stock returns of liberalizing countries behaved the way they did. We show that viewing equity market liberalizations as country IPOs can help resolve these issues.

The paper proceeds as follows. In Section 1, we show the long-run behavior of stock prices around liberalizations. In Section 2, we present an analysis of emerging equity market liberalizations that, drawing on the comparison between IPOs and 
liberalizations, stresses the implications of emerging market corporate governance and investor rights for equity market liberalizations. We conclude in Section 3.

\section{Equity market liberalizations and stock prices.}

The existing literature makes the case that equity market liberalizations decrease the cost of capital in two ways. First, Henry (2000a) shows that stock prices in liberalizing countries increase sharply in the months preceding the liberalization date. This date is when a liberalization event takes place rather than when investors discover that it will happen, so that in an efficient market, the stock price impact of the liberalization should be impounded in prices before the liberalization date. The results of Henry (2000a) are consistent with investors applying a lower discount rate to future expected cash flows after liberalization. Second, Bekaert and Harvey (2000) show that the dividend yield falls after liberalization. If some assumptions are met, the dividend yield is a good proxy for the cost of capital. Both studies conduct various tests to try to make sure that the liberalization effect they identify is not due to confounding factors.

We extend the analysis of the stock-price impact of liberalizations and investigate whether there are similarities in long-run returns between countries that liberalize their equity markets and IPO firms. ${ }^{3}$ In Figure 1 , we show the equally-weighted average cumulative buy-and-hold returns in excess of the risk-free rate of liberalizing countries

\footnotetext{
${ }^{3}$ Existing studies do not agree on equity market liberalization dates for a number of countries. Further, these studies include different countries among the liberalized countries. Rather than attempting to sort out the exact liberalization dates, we study the behavior of stock prices around the liberalization dates used by Bekaert and Harvey (2000) and Henry (2000a), and exclude Japan and New Zealand to focus on emerging markets. Other liberalization dates are provided by Kim and Singal (2000) and Levine and Zervos (1996). Appendix A lists the liberalizations dates and the countries we use. An alternative approach would be to use the dates of depository receipts offerings, which can be viewed as liberalizing events (see Karolyi (2002)). The dates we use precede depository receipts offerings from firms in the countries we consider. Foerster and Karolyi (2000) show that firms have poor returns after depository receipt offerings and Errunza and Miller (2000) show that such offerings reduce the offering firm's cost of capital.
} 
from five years before the liberalization month until five years after the liberalization. This is not a feasible investment strategy since investors did not know which country would liberalize and which would not, but it provides an assessment of stock market performance over the 11-year period surrounding the liberalization. The stock indices we use are the S\&P Emerging Markets Data Base (EMDB) Total Return Indices (U.S. dollar denominated) from December 1975 to September 2000. These indices are not available for all countries for the period we are looking at. Since we are looking for an estimate of what an investor would have received in excess of the risk-free rate had she invested in a liberalizing country starting five years before the liberalization, we only use the countries for which data is available five years before the liberalization in the figure. ${ }^{4}$

Investing in markets that liberalize pays off. The average cumulative buy-andhold excess return is $491 \%$ using the Bekaert and Harvey (2000) liberalization dates and $546 \%$ using the Henry (2000a) liberalization dates. This strong performance of liberalizing countries supports the hypothesis that there is a risk-sharing benefit, but with this hypothesis, we would expect the stock price gains to be incorporated as of the time of the liberalization date. In Figure 1, returns are spectacular after the liberalization month. The general pattern of cumulative returns is similar across countries. For instance, there is no country whose omission from the sample would significantly affect Figure 1. At the same time, however, the magnitude of the cumulative returns varies sharply across countries - but the magnitude of cumulative returns varies also strongly across IPOs.

The large returns of liberalizing countries after the liberalization date seem incompatible with the workings of efficient markets since it would be possible for

\footnotetext{
${ }^{4}$ Our approach is exactly the same as the approach used by Ritter (1991) to estimate buy-and-hold returns of IPO firms. When returns stop being available for a country, we average cumulative excess returns across the remaining countries in the index.
} 
investors to buy stocks in the liberalizing country immediately after the liberalization date and benefit from the subsequent increase in prices. It is necessary to be cautious, however, in interpreting these large returns because, at most, we have 20 liberalizing countries and the event windows over which returns are calculated overlap among these countries. With traditional event studies, the expectation is that when the number of events with non-overlapping windows becomes large, idiosyncratic effects not associated with the event wash out and the resulting event return captures the impact of the event on stock prices. Here, the number of events is small, countries that liberalized may have experienced similar economic shocks, and the clustering may be endogenous. It is also well-known that emerging market returns have fat tails which complicate statistical inference. Further, it is possible that it took time for the markets to learn the implications of equity market liberalizations, so that they initially under-reacted to liberalization events, but they may not do so in the future because investors now understand better the implications of equity market liberalizations. Finally, one should be concerned about the following bias. Except for Chile, the countries in our sample did not reverse their liberalization in the short run. ${ }^{5}$ If markets were unconvinced that the liberalization would last, so that initially investors believed there was a large probability that the liberalization would be reversed, then stock prices would have reflected only partially the impact of the liberalization initially and would have incorporated the benefits of the liberalization fully only as investors became convinced that the liberalization would last. ${ }^{6}$

\footnotetext{
${ }^{5}$ In 1991 the Chilean central bank imposed a one-year unremunerated reserve requirement on foreign funds. Between 1991 and 1997 the coverage of the requirement was extended to cover most forms of foreign funding, with the exception of foreign direct investment. The rate of this requirement was $30 \%$ in May 1992, and was lowered to 10\% in June 1998 (Adams, et. al. 1998).

${ }^{6}$ Perotti and van Oijen (2001) discuss a similar concern in relation to the initiation of country privatization programs where stock prices increased in value sharply after the initiation. Laeven and Perotti (2001)
} 
The striking returns of emerging markets around the liberalization date make it surprising that so few countries have opened their equity markets to foreign investors. Using the 2001 World Development Indicators CD from the World Bank, 36 emerging countries with a population that exceeds 3 million with equity market data had not liberalized their equity market by 1999 , in contrast to 20 emerging countries that had liberalized their equity market.

Another way to look at the data is to compute the yearly average return on an equallyweighted portfolio of countries starting five years before the liberalization year and ending five years after the liberalization year. Using the Bekaert and Harvey (2000) dates, we find that the liberalizing countries in our sample earn $13.44 \%$ per calendar year before the liberalization year, $67.60 \%$ the year of the liberalization, $20.96 \%$ per year in the two years after the liberalization, but $-4.29 \%$ per year in years +3 through +5.1993 was a year with considerable inflows into emerging markets. Seven countries have 1993 in the last three years of the five-year post-liberalization window. If we take out 1993, the average annual return per calendar year in years +3 through +5 is $-12.39 \%$.

We examined returns for liberalizing countries in a number of ways, but the general pattern shown in Figure 1 holds up. The evidence of high returns in the years immediately following the equity market liberalization is stronger than the evidence of subsequent underperformance. Movements in global markets or emerging markets cannot explain the pattern. The evidence of underperformance does not seem robust when the Henry (2000a) dates are used. This could be due to the fact that the Bekaert and Harvey (2000) dates seem more closely associated with an upward shift in flows from foreign

model how a policy change such as a privatization program can gain credibility over time and show that as it does so financial development increases. 
investors, but the result indicates that the choice of liberalization may matter for assessments of long-run performance. ${ }^{7}$ We estimated for each country a regression of the monthly excess return on a constant, the excess return of the world market (using the Datastream world index), the excess return of the emerging markets index (EMBD composite index), a dummy variable corresponding to the event window used by Henry (2000a), which goes from month -7 before the liberalization date to the liberalization month, and a dummy variable for each one of the first five twelve-month periods starting the month immediately after the liberalization. The coefficient on each dummy variable is the average monthly return for the period over which the dummy variable takes a value of one. The emerging market index return is available from January 1985, so that our regressions start then. The average across countries of the dummy variable corresponding to the first twelve-month period following the Bekaert and Harvey (2000) liberalization dates is $4.23 \%$. In contrast, the average for the fifth twelve-month period is $-1.7 \%$, so that liberalizing countries outperform on average by more than $50 \%$ in the first twelve-month period and underperform on average by more than $20 \%$ in the fifth twelve-month period. These averages of the dummy variables are significantly different from zero at the $5 \%$ level.

A similar pattern of spectacular returns followed by disappointing returns is observed for stocks that undergo an initial public offering (IPO). There has been much debate on the statistical significance of the poor performance of IPO firms. Alternate estimation methods lead to different results. It will be even harder to reach a consensus on the longrun performance of liberalizing countries because there are few such countries and a number of liberalization dates are close to each other. Both for equity market

\footnotetext{
${ }^{7}$ See Bekaert, Harvey, and Lumsdaine (2002).
} 
liberalizations and for IPO stocks, there are good reasons to think that some of the corrective market mechanisms that limit valuation departures from fundamentals are more impeded than they are for well-established stocks. When an investor believes that a stock is overvalued, she can attempt to profit from her knowledge by selling the stock short. We know that short-selling is often difficult for IPO stocks; it is also typically difficult for emerging markets stocks because of regulatory restrictions, limited liquidity, and lack of supporting institutions. It would therefore not be surprising if, following an equity market liberalization, prices would be driven up by the most optimistic investors, with a correction eventually taking place.

We examined whether stock returns depend on a proxy for the liquidity of the stock market before liberalization. In a less liquid market, optimistic investors would affect prices more when they trade. When the sample is split, the subsample sizes are more reasonable when we use the Bekaert and Harvey (2000) dates. Using turnover in the year before liberalization as a measure of liquidity, we find that countries with turnover below the median turnover of the liberalizing countries have much stronger returns around the time of the liberalization but poorer returns afterwards. In the calendar year of the liberalization, countries with low turnover earn more than twice what the countries with high turnover earn. However, in the calendar years +3 through +5 following liberalization, the average annual return of the countries with low turnover before liberalization is $-8.73 \%$ and the average annual return of the other countries is $-0.35 \%$. Low turnover markets seem more prone to what appears to be a pattern of overreaction. Figure 2 shows the returns of liberalizing countries for the period of minus seven months before the liberalization date to the liberalization month and for each of the first five 
twelve-month periods afterwards. We also reproduce the return from having invested in the emerging market total return index during these years.

\section{The IPO model of liberalizations.}

Why would a country liberalize its equity market? There are three important reasons why the owners of a private firm would want to take it public: they want to cash out, they require external funding to finance the firm's growth opportunities, or they want to have more equity in the firm's capital structure. ${ }^{8}$ For these arguments to explain why firms in emerging markets want the country to liberalize its equity market, it has to be that the controlling shareholders of the large corporations in a country have a decisive say in whether the equity market is liberalized. This need not be so. Some IMF programs led to greater opening of equity markets. The country might also want to liberalize so that it has a larger market for the shares of privatized firms or for other reasons. ${ }^{9}$ However, we focus here on the motivations of large controlling shareholders. In most countries, one would expect these shareholders to have an important say on the extent to which the equity market is open to foreign investors.

To understand why firms in an emerging country might push for liberalization, it is important to understand that in such a country, firms are closely held. They have a large shareholder or group of shareholders, often a family, with a controlling stake. The average fraction of shares held by controlling shareholders in our sample of liberalizing countries is $53.61 \%$ using the sample drawn from Bekaert and Harvey (2000). ${ }^{10}$ It is most

\footnotetext{
${ }^{8}$ See Pagano, Panetta, and Zingales (1998).

${ }^{9}$ See Boutchkova and Megginson (2000) for evidence on the importance of privatized firms in emerging markets.

${ }^{10}$ We use the data from Dahlquist, Pinkowitz, Stulz, and Williamson (2003). See Appendix B.
} 
likely that before liberalization, ownership was even more concentrated. Consider a typical firm in such a country. By selling a significant fraction of the shares they own, controlling shareholders would take the risk of losing control. If the equity market of that country opens up, foreign investors could own at most $46.39 \%$ of the shares of that firm if the controlling shareholders do not sell some of the shares they own, which limits the extent to which risk-sharing can take place.

For firms to push for liberalization, their controlling shareholders must benefit from it. When are these controlling shareholders likely to favor liberalization? They can benefit from liberalization in many ways, but three benefits stand out, two of which are also the main possible benefits of an IPO for the owners of the firm going public. First, liberalization may provide the controlling shareholders with an exit if they want to reduce their stake in their firm. ${ }^{11}$ Foreign shareholders or a foreign firm could buy their stake. Second, liberalization enables them to raise capital from foreign investors. After liberalization, a firm can have its equity listed on a foreign exchange. This makes it possible, for instance, for the firm to start an ADR program, have an NYSE listing, or raise equity in the U.S. A foreign listing can also help the firm raise capital through debt issues, bank borrowing and private placements. By raising equity capital, the firm can finance new investment or reduce its leverage. Third, an equity market liberalization makes it possible for firms in emerging markets to rent the institutions of more developed countries. Doidge, Karolyi, and Stulz (2003) show that a listing in the U.S. increases firm

\footnotetext{
${ }^{11}$ No paper we know of analyses the impact of the equity market liberalization events of Henry (2000a) or Bekaert and Harvey (2000) on corporate governance and ownership. However, Doidge (2002) investigates how ownership changes after a firm from an emerging market starts an ADR program. He finds that 24 out of 101 firms had a change in control and in 18 of these 24 firms the new controlling shareholder was foreign.
} 
value because, by subjecting the firm to some U.S. laws and regulations, a listing helps make a credible commitment to protect the rights of minority shareholders.

Though the risk-sharing theory of equity market liberalizations implies that these liberalizations necessarily improve welfare, controlling shareholders may be affected adversely by liberalization. Suppose a firm can raise all the funds it requires through banks in the local market, perhaps because of political connections, and the controlling shareholders of the firm have no intention of reducing their stake because doing so would endanger the extent to which they can extract private benefits from control of the firm. In this case, equity market liberalization could help competing firms that are less well established or politically connected in the country by giving them access to outside capital. Perhaps more importantly, following a liberalization, foreign investors will monitor local firms and any actions detrimental to minority shareholders that otherwise might have remained hidden could be exposed by outsiders. This monitoring by foreign investors could therefore make it harder for controlling investors to extract private benefits from the firms they control. Consequently, if a country's largest firms do not have unmet financing needs and if the controlling shareholders of these firms are not looking for an exit, these controlling shareholders are unlikely to push for an equity market liberalization and may actually oppose such a liberalization strongly. ${ }^{12}$

For controlling shareholders of major firms who are not looking for an exit to want the equity market liberalized, it has to be that these firms have growth opportunities that cannot be financed. If that is the case, liberalization takes place when the local market's ability to provide funding to established companies becomes insufficient to

\footnotetext{
${ }^{12}$ It could be that controlling shareholders are in favor of an equity market liberalization, but that it does not take place because the politicians respond to other constituencies.
} 
meet the needs of these companies. The local market could fail in financing local companies because these companies experienced an increase in growth opportunities, because the local market became less able to fund these companies due to internal problems (for instance, a banking crisis), or because controlling shareholders of local firms cannot credibly commit to protect the rights of minority shareholders through the use of local institutions.

For local companies to be able to get funding abroad after not having been able to do so in their home country, they have to draw the attention of foreign investors to the country. This is much like an IPO. For foreign investors to be interested, they have to hear a good story that draws their attention. This suggests that a country is unlikely to liberalize its equity market when its financial system is performing poorly and can no longer fund local firms as well as it did in the past. One would expect instead an equity market liberalization to take place when the country and local firms have improved growth prospects that require additional financing, when foreign investors think that this is the case, or when emerging markets are expected to do well and nothing in the country indicates that its prospects are weaker. However, this means that equity market liberalizations will take place when higher growth is expected. Though Henry (2000b) shows that there is an increase in investment following a liberalization and Bekaert, Harvey, and Lundblad (2002) show that growth increases, the changes they uncover may therefore equally cause the liberalization as being caused by it. Further, because of the difficulties in selling stocks short in liberalizing countries and the limited liquidity of their stock markets, it is plausible that the most optimistic foreign investors might drive prices higher than warranted by fundamentals. Such overreaction would eventually be 
offset by poor stock returns. We saw that the empirical evidence is consistent with such a scenario. The possibility of such a scenario should make us leery of drawing strong conclusions from the data about expected returns following liberalizations.

For an IPO to succeed, there has to be a demand for the firm's shares by public investors. That demand will determine how many shares can be sold at the IPO. For an equity market liberalization to succeed, there has to be a demand for the existing or newly issued shares from firms in the liberalizing country by foreign investors. The success of the liberalization is determined by the extent to which foreign investors buy these shares, but while IPO shares are bought at the IPO price, shares from firms of the liberalizing country are bought at the price at which they trade in that country. Several factors limit the demand for these shares by foreign investors. Some of these factors are similar to those that limit the demand for shares in IPOs, but others are not. In particular, equity market liberalizations do not remove all barriers to holding local equity for foreign investors. Many of the remaining barriers cannot be eliminated by decrees. Countries with weak enforcement of investor rights and poor financial development are necessarily hazardous for foreign investors. Such countries lack transparency, have legal systems that can be manipulated by residents, have expropriation risks, and so on. As a result of these risks for foreign investors, it is still the case after a liberalization that foreign investors can be at a disadvantage relative to domestic investors. Further, while a government decree can reduce barriers to international investment that lead to a home bias on the part of investors, it cannot overcome the behavioral considerations that lead investors to prefer domestic stocks. 
Second, the literature on IPOs emphasizes that the owners of the private firm know more about the firm than potential investors (the information asymmetry problem) and have some ability to take actions after the IPO that benefit them at the expense of the new shareholders (the agency problem). To protect themselves against being taken advantage of, investors are only willing to buy at a lower price than if there were no information asymmetry and agency problems. The owners of the private firm are less likely to take advantage of the public investors if they keep their ownership stake high, because they would then be taking advantage of themselves since they would reduce the value of their stake. This explains why IPO firms typically have concentrated ownership after the IPO. Rational investors would be unlikely to buy the shares of a firm going public where it is known that all the insiders are selling their shares in the IPO. The same issue arises with equity market liberalizations.

Similarly to periods when sentiment is favorable to IPO firms, there are periods when sentiment is favorable to emerging markets, making it more advantageous for countries to liberalize their equity markets, and periods when there is little benefit from making shares available to foreign investors because these investors are reducing their allocation to these markets.

If local firms want to sell equity abroad and if local shareholders want to sell to foreign investors, the more they do so, the more costly it will be for them in terms of the impact on local share prices. Usually, in the case of firms in emerging markets, investors are typically poorly protected. This makes it easier for controlling shareholders to take advantage of minority shareholders. In these countries, concentrated ownership is a mechanism used to control the agency costs of controlling shareholders in that controlling 
shareholders who hold a larger stake in their firm find it more expensive to extract private benefits from control. ${ }^{13}$ Suppose controlling shareholders own a fraction w of the firm's cash flows. When these shareholders extract from the firm $\$ 1$ of private benefits, they would get $\$ \mathrm{w}$ of that $\$ 1$ in any case. If it costs the firm $\$ \mathrm{x}$ to extract $\$ 1$ of private benefits, controlling shareholders pay $\$ w x$ to get $\$(1-w)$. The greater w, the lower the net benefit to shareholders from extracting private benefits from the firm. As the fraction of cash flows owned by controlling shareholders falls because of new equity issued, the price of shares falls because the incentives of controlling shareholders to extract private benefits increase. Even though controlling shareholders can take actions to limit this effect, they cannot eliminate it. Consequently, the ability of firms to take advantage of an equity market liberalization is limited by the extent to which investor protection in the local market makes it optimal for cash flow ownership by controlling shareholders to be high. As investor protection improves, firms in a country become better able to take advantage of their ability to raise capital from foreign investors.

\section{Conclusion.}

In this paper, we argue that viewing equity market liberalizations as country IPOs provides the basis for a more useful model of equity market liberalizations than the simple risk-sharing model. Viewing equity market liberalizations as country IPOs forces us to take into account the endogeneity of equity market liberalizations and to acknowledge that the short-run impact of equity market liberalizations does not provide a complete picture of how liberalizations affect countries. Perhaps even more importantly,

\footnotetext{
${ }^{13}$ See Shleifer and Wolfenzon (2002).
} 
how much a country benefits from an equity market liberalization depends on the extent to which firms can take advantage of the liberalization.

In the long run, the ability of firms to benefit from an equity market liberalization depends on corporate governance and on the protection of investor rights. Because of the limited financial development and investor protection in liberalizing countries, stock prices may overreact following an equity market liberalization and risk-sharing can only be limited. For countries to gain more from equity market liberalizations, they have to improve their financial development and the degree to which they protect investors. With greater financial development, stock prices are less likely to overreact to purchases or sales by foreign investors. With greater investment protection, shares will be more diffusively owned and foreigners will be less at a disadvantage, which will enable foreign investors to participate more in local markets. 


\section{Bibliography}

Adams Charles, Donald J. Mathieson, Garry Schinasi, and Bankim Chadha, 1998. International Capital Markets Developments, Prospects, and Key Policy Issues, Annex IV, International Monetetary Fund, Washington, D.C.

Bekaert, Geert, and Campbell Harvey, 2000, Foreign Speculators and Emerging Equity Markets, Journal of Finance, v55(2), pp. 565-613.

Bekaert, Geert, Campbell Harvey, and Robin Lumsdaine, 2002, Dating the Integration of World Capital Markets, Journal of Financial Economics 65, pp. 203-247.

Bekaert, Geert, Campbell Harvey, and Christian Lundblad, 2002, Does Financial Liberalization Spur Growth?, Working Paper, Duke University, Durnham, NC.

Boutchkova, Maria K., and William L. Megginson, 2000, Privatization and the Rise of Global Capital Markets, Financial Management, Vol. 29, Number 4, pp $31-76$.

Dahlquist, Magnus, Lee Pinkowitz, René M. Stulz, and Rohan Williamson, 2003, Corporate Governance and the Home Bias, Journal of Financial and Quantitative Analysis, forthcoming.

Doidge, Craig, 2002, Do Laws Matter for Corporate Ownership and Control? Evidence from emerging markets firms that list in the U.S., working paper, University of Toronto, Toronto, Canada.

Doidge, Craig, G. Andrew Karolyi, and René M. Stulz, 2003, Why Are Foreign Firms that List in the U.S. Worth More?, Journal of Financial Economics, forthcoming.

Errunza, Vihang R. and Darius P. Miller, 2000, Market Segmentation and the Cost of Capital in International Equity Markets, Journal of Financial and Quantitative Analysis 35, pp. 577-600.

Foerster, Stephen, and Karolyi, G. Andrew, 2000, The Long Run Performance of Global Equity Offerings, Journal of Financial and Quantitative Analysis 35, pp. 499-528.

Henry, Peter Blair, 2000a, Stock Market Liberalization, Economic Reform and Emerging Market Equity Prices, Journal of Finance, v55(2), pp. 529-564.

Henry, Peter Blair, 2000b, Do Stock Market Liberalizations Cause Investment Booms?, Journal of Financial Economics 58, pp. 301-330.

Karolyi, G. Andrew, 2002, The Role of ADRs in the Development and Integration of Emerging Equity Markets, working paper, The Ohio State University, Columbus, $\mathrm{OH}$. 
Kim, E. Han, and Vijay Singal, 2000, Stock Markets Openings: Experience of Emerging Economies, Journal of Business 73, pp. 25-66.

Laeven, Luc, and Enrico C. Perotti, 2001, Confidence Building in Emerging Stock Markets, CEPR working paper No. 3055, CEPR, London, England.

Levine, Ross, and Sara Zervos, 1996, Capital Control Liberalization and Stock Market Development, Policy Research Working Paper No. 1622, The World Bank, Washington, D.C.

Pagano Marco, Fabio Panetta and Luigi Zingales, 1998, Why do Companies go Public? An Empirical Analysis, The Journal of Finance, Vol 53, pp 27-64.

Perotti, Enrico C., and Pieter Van Oijen, 2001, Privatization, Political Risk and Stock Market Development in Emerging Economies, Journal of International Money and Finance, Vol 20, pp. 43-69.

Ritter, Jay R., 1991, The Long-run Performance of Initial Public Offerings, The Journal of Finance, Vol 46, No. 1, pp. 3-27.

Ritter, Jay R., and Ivo Welch, 2002, A review of IPO Activity, Pricing, and Allocations, The Journal of Finance, Vol 57, No. 4, pp 1795 - 1828.

Shleifer, Andrei, and Daniel Wolfenzon, 2002, Investor Protection and Equity Markets, Journal of Financial Economics, Vol 66, No. 1, pp. 3-27.

Stulz, René M., 2003, Should We Fear Capital Flows?, in International Financial Markets: The Challenge of Globalization, Leonardo Auernheimer (Editor), University of Chicago Press, Chicago, Ill., forthcoming. 


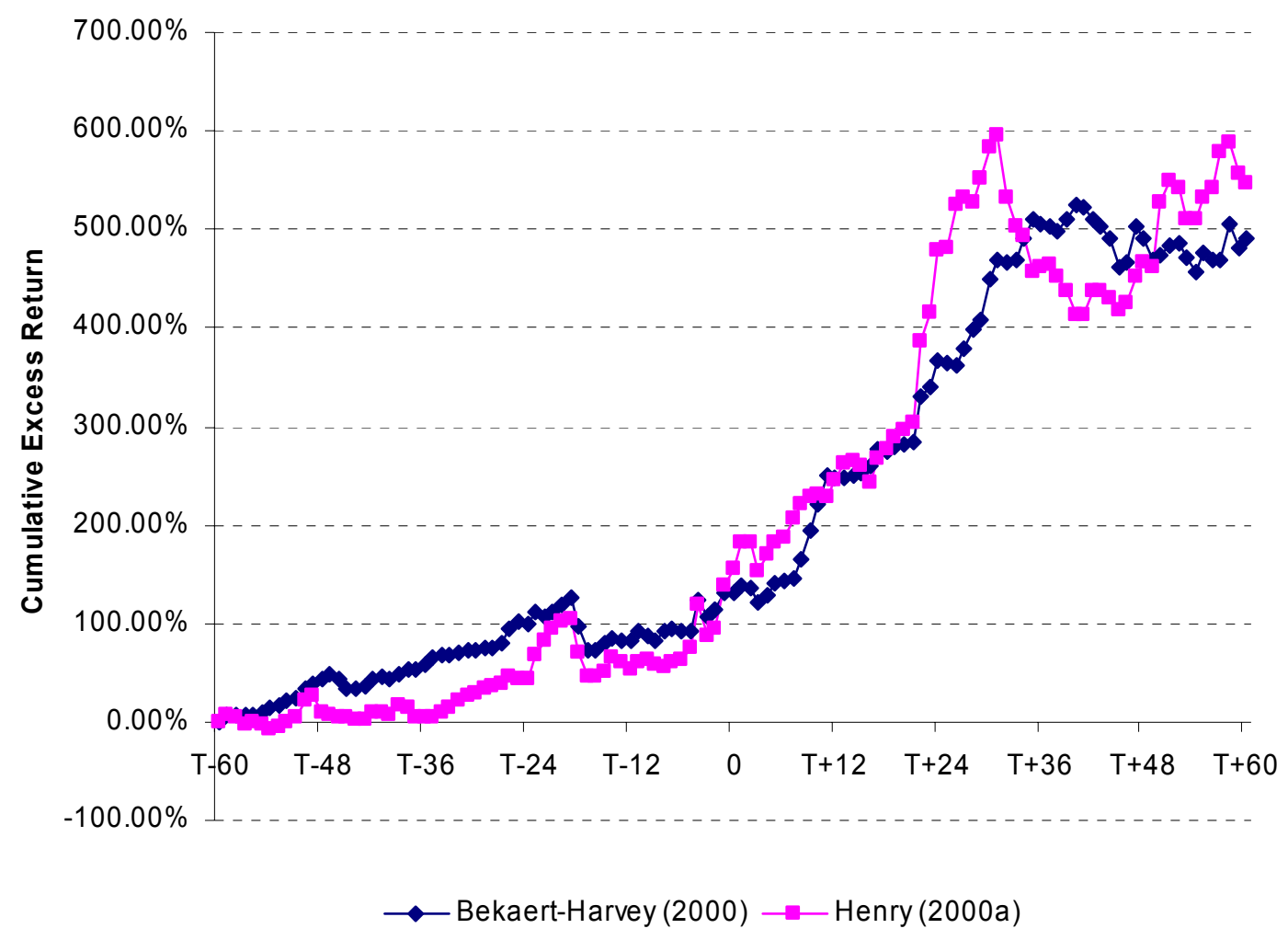

Figure 1 Average cumulative buy and hold excess return of liberalizing countries

The figure shows the average cumulative buy and hold dollar return of liberalizing countries in excess of the dollar risk-free rate. The countries used in the sample are the 15 liberalizing countries that have returns in the EMDB database starting five-years before the liberalization. The liberalization countries and dates are either drawn from Bekaert and Harvey (2000) or from Henry (2000a). 


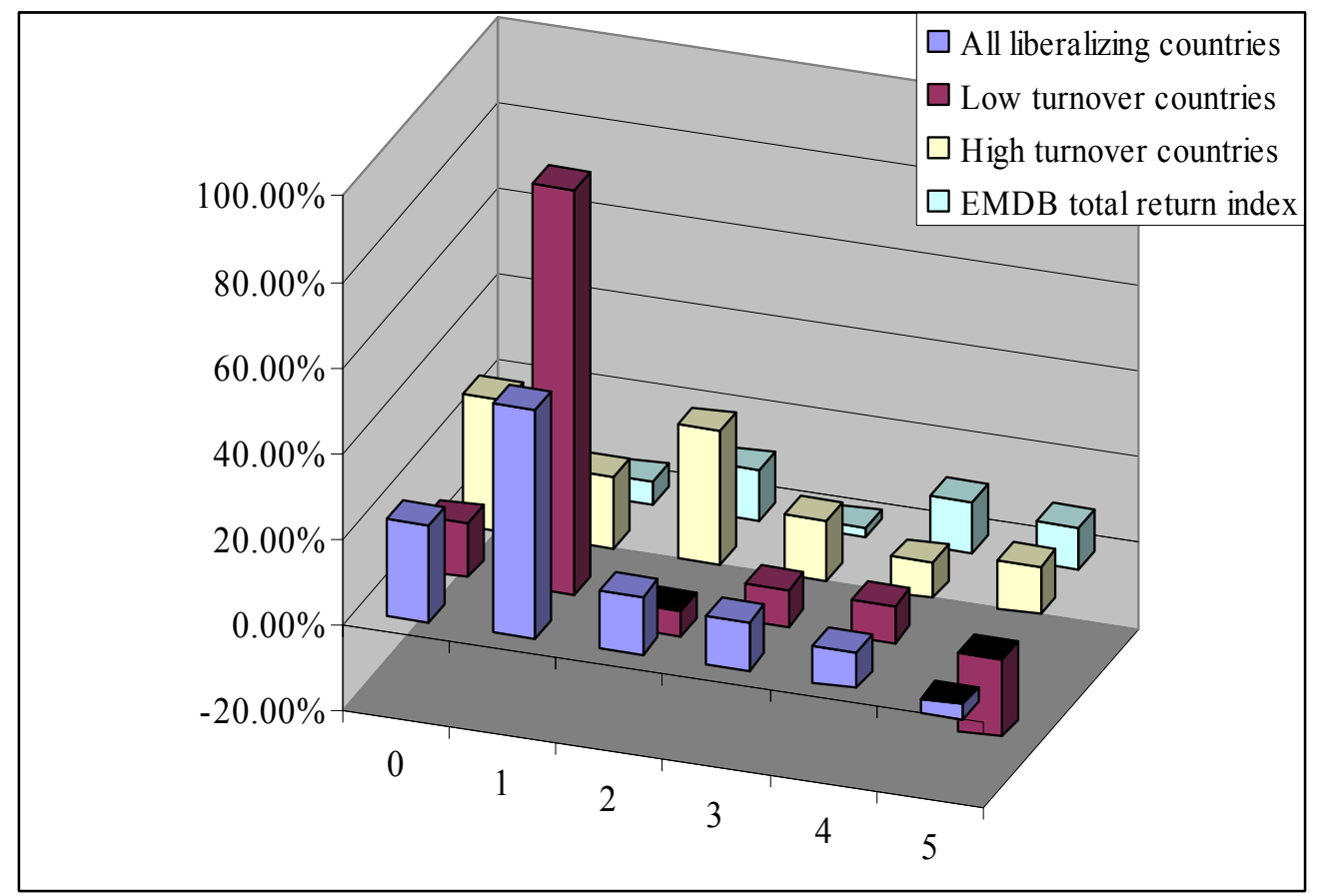

Figure 2. Stock returns and equity market liberalization.

This figure shows the returns of liberalizing countries during the period (period 0 in the figure) from month -7 to the month of the liberalization, and of each of the first five twelve-month periods from month +1 (periods 1 to 5). The returns are the total return indices from the Emerging Markets Data Base (EMDB). A liberalizing country is included in the sample for any year in which it has a return in EMDB. 


\section{Appendix A. Liberalization dates across different previous studies.}

This table lists the liberalization dates from Henry (2000a), Bekeart and Harvey (2000), Levine and Zervos (1996), and Kim and Singal (2000).

\begin{tabular}{|c|c|c|c|c|c|c|c|c|}
\hline \multirow[b]{2}{*}{ Country } & \multicolumn{2}{|c|}{ Bekaert and Harvey (2000) } & \multicolumn{2}{|r|}{ Henry (2000a) } & \multicolumn{2}{|c|}{ Levine and Zervos (1996) } & \multicolumn{2}{|c|}{ Kim and Singal (2000) } \\
\hline & $\begin{array}{c}\begin{array}{c}\text { Liberalization } \\
\text { date }\end{array} \\
\end{array}$ & Event & $\begin{array}{c}\begin{array}{c}\text { Liberalization } \\
\text { date }\end{array} \\
\end{array}$ & Event & $\begin{array}{c}\begin{array}{c}\text { Liberalization } \\
\text { date }\end{array} \\
\end{array}$ & Event & $\begin{array}{c}\begin{array}{c}\text { Liberalization } \\
\text { date }\end{array} \\
\end{array}$ & Event \\
\hline Argentina & Nov-89 & New foreign investment decree & Nov-89 & New foreign investment decree & Jun-80 & $\begin{array}{l}\text { Eased restrictions on foreign } \\
\text { portfolio investment in Argentina }\end{array}$ & Nov-89 & New foreign investment decree \\
\hline Brazil & May-91 & $\begin{array}{l}\text { Foreign investment law changed. } \\
\text { Investors can now hold up to } \\
49 \% \text { of voting stock and } 100 \% \text { of } \\
\text { non voting stock }\end{array}$ & Mar-88 & Country fund introduction & Jun-90 & $\begin{array}{l}\text { Liberalized capital repatriation } \\
\text { and capital inflow restrictions }\end{array}$ & May-91 & $\begin{array}{l}\text { Foreign investment law changed. } \\
\text { Investors can now hold up to } \\
49 \% \text { of voting stock and } 100 \% \text { of } \\
\text { non voting stock }\end{array}$ \\
\hline Chile & Jan-92 & $\begin{array}{l}\text { Ease of restrictions on } \\
\text { repatriation of capital. Coincides } \\
\text { with broad economic reform }\end{array}$ & May-87 & Country fund introduction & Jan- 88 & $\begin{array}{l}\text { Liberalized repatriation of } \\
\text { dividends }\end{array}$ & Oct-89 & First country fund admitted \\
\hline Colombia & Feb-91 & $\begin{array}{l}\text { Resolution } 49 \text {, foreigners are } \\
\text { given same rights as domestic } \\
\text { investors, } 100 \% \text { remittances and } \\
\text { equal access to local credit } \\
\text { sources }\end{array}$ & Dec-91 & $\begin{array}{l}\text { Policy Decree: Resolution } 52, \\
\text { foreign investors are allowed to } \\
\text { purchase up to } 100 \% \text { of locally } \\
\text { listed companies }\end{array}$ & Dec-89 & $\begin{array}{l}\text { Eased portfolio and direct foreign } \\
\text { investment restrictions }\end{array}$ & Feb-91 & $\begin{array}{l}\text { Policy Decree: Resolution } 52, \\
\text { foreign investors are allowed to } \\
\text { purchase up to } 100 \% \text { of locally } \\
\text { listed companies }\end{array}$ \\
\hline Greece & Dec-87 & $\begin{array}{l}\text { Liberalization of currency } \\
\text { controls }\end{array}$ & & & & & Aug-86 & $\begin{array}{l}\text { European Community nationals } \\
\text { are allowed to invest in Greek } \\
\text { securities }\end{array}$ \\
\hline India & Nov-92 & $\begin{array}{l}\text { Government allowed foreign } \\
\text { portfolio investors to invest in } \\
\text { Indian listed securities }\end{array}$ & Jun-86 & Country fund introduction & May-90 & $\begin{array}{l}\text { Automatic approval of foreign } \\
\text { investment proposals of foreign } \\
\text { companies with equity share up } \\
\text { to } 40 \%\end{array}$ & Nov-92 & $\begin{array}{l}\text { Government allowed foreign } \\
\text { portfolio investors to invest in } \\
\text { Indian listed securities }\end{array}$ \\
\hline Indonesia & Sep-89 & $\begin{array}{l}\text { Minister of Finance allows } \\
\text { foreigners to buy up to } 49 \% \text { of } \\
\text { listed firms except financial firms }\end{array}$ & & & & & Sep-89 & $\begin{array}{l}\text { Minister of Finance allows } \\
\text { foreigners to buy up to } 49 \% \text { of } \\
\text { listed firms except financial firms }\end{array}$ \\
\hline Jordan & Dec-95 & $\begin{array}{l}\text { Foreigners allowed to purchase } \\
\text { without government approval }\end{array}$ & & & Jan-87 & Liberalized capital repatriation & Jan-78 & $\begin{array}{l}\text { Amman Stock Exchange opens. } \\
\text { Investors are allowed to own } \\
49 \% \text { of equity }\end{array}$ \\
\hline \multirow[t]{2}{*}{ Korea } & Jan-92 & $\begin{array}{l}\text { Stock market opens to investors, } \\
\text { foreigners cannot own more than } \\
3 \% \text { individually and } 10 \% \\
\text { collectively }\end{array}$ & Jun-87 & Country fund introduction & Aug-81 & $\begin{array}{l}\text { Liberalized inflows and outflows } \\
\text { of direct foreign investment }\end{array}$ & Jan-92 & $\begin{array}{l}\text { Stock market opens to investors, } \\
\text { foreigners cannot own more than } \\
3 \% \text { individually and } 10 \% \\
\text { collectively }\end{array}$ \\
\hline & & & & & Feb-92 & $\begin{array}{l}\text { Liberalized portfolio inflows and } \\
\text { outflows }\end{array}$ & & \\
\hline
\end{tabular}


Bekaert and Harvey (2000)

\begin{tabular}{|c|c|c|}
\hline Country & $\begin{array}{l}\text { Liberalization } \\
\text { date }\end{array}$ & Event \\
\hline Malaysia & Dec-88 & $\begin{array}{l}\text { Liberalization of foreign } \\
\text { ownership policies }\end{array}$ \\
\hline Mexico & May- 89 & $\begin{array}{l}\text { Relaxation of } 1973 \text { law } \\
\text { controlling foreign investment. } \\
\text { Tax amnesty for capital } \\
\text { repatriation }\end{array}$ \\
\hline Nigeria & Aug-95 & $\begin{array}{l}\text { Government repeals the } \\
\text { Exchange Control Act of } 1962 \\
\text { and Enterprise Promotion Act of } \\
1989\end{array}$ \\
\hline Pakistan & Feb-91 & $\begin{array}{l}\text { Relaxation of both domestic an } \\
\text { foreign investment procedures }\end{array}$ \\
\hline Philippines & Jun-91 & $\begin{array}{l}\text { Foreign Investment Act is signe } \\
\text { It removes, over three years, all } \\
\text { restrictions on foreign } \\
\text { investments }\end{array}$ \\
\hline Portugal & Jul-86 & Portugal enters the EC \\
\hline Taiwan & Jan-91 & $\begin{array}{l}\text { Implementation of second phase } \\
\text { of liberalization plan. Foreign } \\
\text { institutional investors can now } \\
\text { invest directly if they have } \\
\text { received approval as qualified } \\
\text { foreign institutional investor. }\end{array}$ \\
\hline
\end{tabular}

Thailand

Turkey

Venezuel

Aug-8

Jan-90

Zimbabwe

of Thailand's Alien Board

Communiqué passes allowing foreign mutual funds to have
access to equities market

Decree 727 , opening the marke

(except banks) to foreign

investors
Henry (2000a)
Liberalization

date

May-87

May-89

titutional investor.
New investment guidelines and

open the Zimbabwe Stock

Exchange to foreign portfolio

investment

\section{Levine and Zervos (1996)}

\section{Event}

Country fund introduction

Policy Decree: Liberalization of

foreign portfolio inflows

\section{alization}

date

Nov-86

May-89

Liberalization of direct foreign investment and portfolio inflow restrictions

Liberalized direct foreign

investment inflows

Jan-9

Liberalized dividend and capital repatriation $\begin{array}{ll}\text { Jan-88 } & \begin{array}{l}\text { Liberalized dividend and capital } \\ \text { repatriation }\end{array}\end{array}$

Liberalized dividend repatriation

Feb-91

Opened stock market to foreign investment

Liberalized capital and dividen repatriation

Feb-90 liberalizing portfolio inflows an outflows

Policy Decree: Decree 727, opening the market (except banks) to foreign investors
Jan-90 Liberalized direct foreign investment and portfolio inflow

\section{Kim and Singal (2000)}

\section{Liberalization Event}

Fior to 1985 Most stocks were already $100 \%$ available to investors

May-89 Foreign investment now allowed up to $100 \%$ in $73 \%$ of Mexico's 754 economic sectors

Feb-

Jan-91 Foreigners are allowed to own $100 \%$ of companies except arms sector

Opening of stock market,

foreigners can invest up to $10 \%$ subject to overall limit

"Foreign Board" was established as a parallel stock exchange for trading shares that could be hold by foreigners

Aug- $89 \quad$ Market considered $100 \%$ open by IFC

Jan-90

Decree 727 , opening the market (except banks) to foreign

investors

Jul-93 Foreigners allowed to purchase up to $25 \%$ of listed shares 


\section{Appendix B. Average fraction of shares held by controlling shareholders}

The data is from Dahlquist, Pinkowitz, Stulz, and Williamson (2003).

\section{Bekaert and Harvey (2000) sample}

Country Percentage of market capitalization closely held

$\begin{array}{ll}\text { Argentina } & 52.68 \\ \text { Brazil } & 67.13 \\ \text { Chile } & 64.94 \\ \text { Colombia } & \text { NA } \\ \text { Greece } & 75.18 \\ \text { India } & 40.32 \\ \text { Indonesia } & 68.97 \\ \text { Jordan } & 65.55 \\ \text { Korea } & 39.23 \\ \text { Malaysia } & 52.15 \\ \text { Mexico } & 26.15 \\ \text { Nigeria } & \mathrm{NA} \\ \text { Pakistan } & 77.37 \\ \text { Philippines } & 51.13 \\ \text { Portugal } & 35.04 \\ \text { Taiwan } & 22.26 \\ \text { Thailand } & 57.83 \\ \text { Turkey } & 70.86 \\ \text { Venezuela } & 61.53 \\ \text { Zimbabwe } & 36.63 \\ & \\ \text { Average } & 53.61\end{array}$

\section{Henry (2000a) sample}

Country Percentage of market capitalization closely held

$\begin{array}{ll}\text { Argentina } & 52.68 \\ \text { Brazil } & 67.13 \\ \text { Chile } & 64.94 \\ \text { Colombia } & \text { NA } \\ \text { India } & 40.32 \\ \text { Korea } & 39.23 \\ \text { Malaysia } & 52.15 \\ \text { Mexico } & 26.15 \\ \text { Philippines } & 51.13 \\ \text { Taiwan } & 22.26 \\ \text { Thailand } & 57.83 \\ \text { Venezuela } & 61.53 \\ & \\ \text { Average } & 51.31\end{array}$

